\title{
Comparing Political Support in Bulgaria (1990 - 2001 - 2011)
}

\author{
Svetlana Stamenova* \\ Bulgarian Academy of sciences, Sofia, Bulgaria
}

Submission: March 06, 2018; Published: May 21, 2018

*Corresponding author: Svetlana Stamenova, Bulgarian Academy of sciences, Sofia, Bulgaria, Email: stamenova.svetlana88@gmail.com

Keywords: Democratic system; Political Support; Cluster; Honeymoon period; Hypothesis; Grades scale; Government; Post-communist transition; Decade; Public opinion; Alienation; Ideologies; Trust; Imminent feature; Multi-party system; Authorities

\section{Introduction}

The study is based on data analysis from three public opinion surveys based on representative cluster samples of all Bulgarian population over 18 years of age [1].

The main questions we are trying to answer are:

a. Is there a disappointment of the democratic system in Bulgaria among the Bulgarian citizens twenty-one years after the change of the political system?

b. Is there a reduction or increase of the number of citizens who support the new democratic political system in 2001 and in 2011 as compared with 1990 ?

c. What are the changes in the trust in the institutions from 1990 to 2011 ?

The studies of political support at the beginning of the systemic change in the East and Central Europe show that the start of the transition is characterized with a quite high mass support for democracy that was called "honeymoon period" [2,3]. We will try to check out at what point of time this "honeymoon effect" evaporates in Bulgaria due to the economic and social and political hardship of the transition period there.

\section{Results}

The first step in our analysis was to make a comparison of the means of the index of the support for the principles of democratic order in 1990, 2001 and 2011. The comparison of the means confirm the hypothesis about the existence of generalized trust in the new regime and a "honeymoon period" in support for democracy at the beginning of the systemic change in Bulgaria (1990), which started to evaporate during the next ten years. Thus, in 1990 the mean of the index of support for democratic principles is 8.23 in 10 grades scale, and in 2001 the mean is 6.22 and is kept without change ten years later - in 2011.

\section{The Trust to Institutions and Ruling Authorities}

The trust to institutions also shows a dramatic decline for eleven years from 1990 to 2001 . After the collapse in 2001, the next ten years period is characterized by a slower reduction in the trust to institutions. For example, the trust to political parties falls almost three times (by 36\%) for eleven years period from 1990 to 2001 and for the next decade from 2001 to 2011 the confidence in political parties goes down by $3 \%$. At the same time, the lack of trust to political parties increased by $44 \%$ in 2001 and by another 5\% in 2011 .

On the question "Generally speaking, would you say that the country is run by few big interests looking out for themselves or that is run for the benefit of all people?", the increase is on the side of the opinion that the country is run by few big interests looking out for themselves - it triples in 2001 (rises by $46 \%$ ), and for a decade from 2001 to 2011 it is kept almost the same. Thus, in 1990 this opinion is supported by $27 \%$ of the Bulgarians, and in 2001 and 2011 - by around $75 \%$. Those who think that the country is run for the benefit of all people decrease more than four times for two decades - in 1990 54\% share this view, and in 2011 - only 13\%. This data shows an immense fall in generalized trust to the ruling authorities and the existence of a significant alienation of the population from the ruling political class eleven years after the beginning of the systemic change. The next decade from 2001 to 2011 kept the level, which was reached in the previous decade - from 1990 to 2001.

\section{Support for Democratic Principles}

As already mentioned above, the support for democratic principles is also vastly declining during the first decade of post-communist transition. For example, on the question "What do you think will be better for our country - one-party system or multi-party system?" those citizens who chose one-party 
system almost doubled in 2001, and a decade later they tripled as compared with 1990 . Those who prefer multi-party system decline by $20 \%$ in 2001 and by another $4 \%$ a decade later - in 2011. On the question "Do you think the elections are the best way to choose government?" those who respond positively decline by $24 \%$ in 2001 and those who respond negatively tripled.

In 2011 we observe some signs of polarization of public opinion about the principles of the democratic regime, in which often there is an increase of both positive and negative positions at the expense of those who have not clear opinion. The negative responses, however, increase more than the positive ones. Thus, the identification of democracy with the multi-party system decreases by $13 \%$ in 2001 , but rise by $9 \%$ in 2011 . However, those who do not recognize multi-party system as an imminent feature of democracy almost triple in 2001 and rise four times in 2011 as compared to 1990 . Also, the ideologies of the beginning of the post-communist transition which equalize democracy with greater social equality, economic prosperity and more working places are almost destroyed in 2001. During the next decade from 2001 to 2011, however, there is a partial recovery of those who support these ideologies, which is accompanied by a polarization of the opinions due to an increase also of those who lost their confidence in democracy

\section{Conclusion}

After the "honeymoon period" in the support for democracy, which is a characteristic of the start of the post-communist transition in all central d East European countries, in Bulgaria in 2001 there is more than serious collapse of the trust in the political system and a significant change in the support for democratic principles with a tendency of rejection of such characteristics of the new democratic order as multi-party system, elections, freedom of speech. The next decade (20012011) is a time of more than modest partial restoration of the trust to some democratic principles, but this modest restoration is too weak in order to reach the levels of support for democracy of 1990. This 2011 recovery is accompanied by enhanced polarization and increase of those who do not share the democratic principles. We can conclude that there was a significant disappointment from the democratic system in Bulgaria and that this disappointment happens during the first decade of the systemic change. The second decade did not change much the picture of the public opinion, created in 2001.

\section{References}

1. These surveys are: the international survey of J. Simon from the Institute of political science, the Hungarian Academy of Sciences, that has been collected in Bulgaria in December 1991, the national survey of S. Stamenova and G. Ganev from the Centre for liberal strategies, conducted in March 2001, and the national survey of S. Stamenova and B. Ermenov, funded by the Bulgarian Ministry of Education and conducted in December 2011, Bulgaria.

2. Weil F (1989) The sources and structure of democratic legitimation in Western democracies: A consolidated model tested with time-series data in six countries since the WWII/American Sociological Review 54: 682-706.

3. Toka G (1995) Being represented - being satisfied? Citizens and the State. In: Kilngemann HD, Fuchs D (Eds.), Oxford University Press, Oxford, UK, pp. 352-382.

\section{Your next submission with Juniper Publishers will reach you the below assets}

- Quality Editorial service

- Swift Peer Review

- Reprints availability

- E-prints Service

- Manuscript Podcast for convenient understanding

- Global attainment for your research

- Manuscript accessibility in different formats

( Pdf, E-pub, Full Text, Audio)

- Unceasing customer service

Track the below URL for one-step submission https://juniperpublishers.com/online-submission.php 